\title{
Effect of Drying Conditions on the Catalytic Performance, Structure, and Reaction Rates over the Fe-Co-Mn/MgO Catalyst for Production of Light Olefins
}

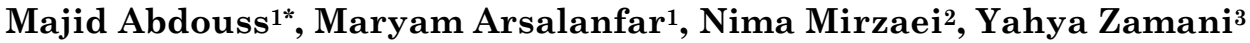 \\ ${ }^{1}$ Department of chemistry, Amirkabir University of technology, Hafez Ave, Tehran, Iran \\ ${ }^{2}$ Department of Chemical and Petroleum Engineering, Sharif University of Technology, Azadi \\ Avenue, P.O. Box 11365-9465, Tehran, Iran \\ ${ }^{3}$ Research Institute of Petroleum Industry of the National Iranian Oil Company, Gas Research \\ Division, P.O. Box 18745-4163, Tehran, Iran
}

Received: 21st May 2017; Revised: 29th August 2017; Accepted: $7^{\text {th }}$ September 2017;

Available online: 22nd January 2018; Published regularly: 2nd April 2018

\begin{abstract}
The MgO-supported Fe-Co-Mn catalysts, prepared using co-precipitation procedure, were tested for production of light olefins via $\mathrm{CO}$ hydrogenation reaction. The effect of a range of drying conditions including drying temperature and drying time on the structure and catalytic performance of $\mathrm{Fe}-\mathrm{Co}-\mathrm{Mn} / \mathrm{MgO}$ catalyst for Fischer-Tropsch synthesis was investigated in a fixed bed micro-reactor under the same operational conditions of $\mathrm{T}=350^{\circ} \mathrm{C}, \mathrm{P}=1 \mathrm{bar}, \mathrm{H}_{2} / \mathrm{CO}=2 / 1$, and GHSV $=4500 \mathrm{~h}^{-1}$. It was found that the catalyst dried at $120^{\circ} \mathrm{C}$ for $16 \mathrm{~h}$ has shown the best catalytic performance for $\mathrm{CO}$ hydrogenation. Furthermore, the effect of drying conditions on different surface reaction rates was also investigated and it was found that the precursors drying conditions influenced the rates of different surface reactions. Characterization of catalyst precursors and calcined samples (fresh and used) was carried out using powder X-ray Diffraction (XRD), Scanning Electron Microscopy (SEM), Energy Dispersive Spectroscopy (EDS), Brunauer-Emmett-Teller (BET) measurements, Temperature Programmed Reduction (TPR), Thermal Gravimetric Analysis (TGA), and Differential Scanning Calorimetry (DSC). Characterization results showed that different investigated variables (drying conditions) influenced the structure, morphology and catalytic performance of the ternary catalysts. Copyright () 2018 BCREC Group. All rights reserved
\end{abstract}

Keywords: Fe-Co-Mn catalyst; Drying conditions; CO hydrogenation; Characterization; Surface reactions rate

How to Cite: Abdouss, M., Arsalanfar, M., Mirzaei, N., Zamani, Y. (2018). Effect of Drying Conditions on the Catalytic Performance, Structure, and Reaction Rates over the Fe-Co-Mn/MgO Catalyst for Production of Light Olefins. Bulletin of Chemical Reaction Engineering \& Catalysis, 13 (1): 97-112 (doi:10.9767/bcrec.13.1.1222.97-112)

Permalink/DOI: https://doi.org/10.9767/bcrec.13.1.1222.97-112

\section{Introduction}

In recent years, it is highly desired to establish the practical method of producing clean al-

* Corresponding Author.

E-mail: phdabdouss44@aut.ac.ir (Abdous, M.) ternative fuels from the aspects of environmental preservation and energy security [1]. Natural resources, such as coal, natural gas and biomass, can be converted into liquid hydrocarbon fuels via the Fischer-Tropsch synthesis (FTS) reaction [2]. Reactants $\left(\mathrm{CO}+\mathrm{H}_{2}\right)$ through this reaction are converted to an array of long 
chain molecules, mainly consisting of $\mathrm{n}$ paraffins and 1- and 2-olefins:

$$
\begin{aligned}
& n \mathrm{CO}+(2 n+1) \mathrm{H}_{2} \rightarrow \mathrm{C}_{n} \mathrm{H}_{2 n+2}+n \mathrm{H}_{2} \mathrm{O} \\
& \quad n=1,2,3, \ldots \\
& n \mathrm{CO}+2 n \mathrm{H}_{2} \rightarrow \mathrm{C}_{n} \mathrm{H}_{2 n}+\mathrm{nH}_{2} \mathrm{O} \\
& n=2,3,4, \ldots
\end{aligned}
$$

Because of producing low aromatics [3], zero sulfur [4], and low pollutant emission [5], FTS has been regarded as one of the most technical feasible process for environmental conversion of natural gas into ultra-clean liquid products $[6,7]$. The FTS process was shown to be catalyzed by certain transition metals, such as: Co, $\mathrm{Fe}$, and $\mathrm{Ru}$, which present the highest activity [8]. Up to now, only iron and cobalt based catalysts have been found to be cost-effective and economical for industrial application [9-12]. Compared with cobalt catalysts, iron catalysts can be operated under wider range of temperatures and $\mathrm{H}_{2} / \mathrm{CO}$ ratios with low $\mathrm{CH}_{4}$ selectivity. Especially, $\mathrm{Fe}$ catalysts exhibit much higher activity for the water gas shift (WGS) reaction, which is helpful for the conversion of syngas with lower $\mathrm{H}_{2} / \mathrm{CO}$ ratios derived from coal or biomass. In addition, linear alkane fuels, alkenes and oxygenates can be obtained through iron catalysts. However, the rapid catalyst deactivation is still a big challenge for Fe catalysts [13]. Comparatively, cobalt catalysts are preferred due to their high activity, high selectivity to long-chain paraffins, low WGS activity, and high resistance to deactivation by water [14].

The mixing of metal components has a great effect on the activity and selectivity because of the possible electronic interaction between metal species [15]. Fe-Mn and Co-Mn catalysts favour $\mathrm{C}_{2}-\mathrm{C}_{4}$ olefins $[16,17]$ rather than the other $\mathrm{Fe}$ or Co-based bimetallic catalysts. The Co-Mn catalysts are mainly composed of metallic cobalt particles dispersed in $\mathrm{MnO}$ [18], but $\mathrm{Fe}-\mathrm{Co}$ catalyst favour intermetallic alloy formation [19,20]. The addition of $\mathrm{Mn}$ to $\mathrm{Fe}$ or Co catalysts brought about a significant increase in light olefins formation and a decrease in methane selectivity [21-23]. In our previous work we used the Fe-Co-Mn ternary catalyst for the first time and investigate different preparation and operational conditions over this catalyst for CO hydrogenation [24-27]. In the present work we investigate the effect of drying conditions on the catalytic performance and catalyst structure of co-precipitated $\mathrm{Fe}-\mathrm{Co}$ Mn catalyst and also investigate different surface reaction rates.

The main objectives of the present work are: (1) preparation of $\mathrm{Fe}-\mathrm{Co}-\mathrm{Mn} / \mathrm{MgO}$ catalysts un- der different precursor drying conditions including precursor drying temperature and time; (2) evaluation of all of the obtained catalysts under the same process conditions for $\mathrm{CO}$ hydrogenation; (3) characterization and investigation of the structure and physico-chemical properties of the precursors and calcined catalysts; (4) investigation of different surface reaction rates over these different prepared catalysts. Structural investigation of the catalysts and precursors was carried out using various techniques of XRD, BET, SEM, TPR, TGA, and DSC.

\section{Materials and Methods}

\subsection{Catalyst preparation}

The supported Fe-Co-Mn-based catalysts were prepared via co-precipitation method. In the co-precipitation procedure aqueous solutions of $\mathrm{Co}\left(\mathrm{NO}_{3}\right)_{2} \cdot 6 \mathrm{H}_{2} \mathrm{O}$ (2M) (99\% Merck), $\mathrm{Fe}\left(\mathrm{NO}_{3}\right)_{3} .9 \mathrm{H}_{2} \mathrm{O} \quad(2 \mathrm{M}) \quad(99 \quad \% \quad$ Merck $)$ and $\mathrm{Mn}\left(\mathrm{NO}_{3}\right)_{2} .4 \mathrm{H}_{2} \mathrm{O}$ (2M) (99 \% Merck) with the same molar ratios were premixed and then the $10 \mathrm{wt} \%$ of $\mathrm{MgO}$ (based on the total catalyst weight) was added to the obtained mixed solution of cobalt, iron and manganese nitrates. The resulting solution was heated to $70{ }^{\circ} \mathrm{C}$ in around bottomed flask fitted with a condenser. Aqueous $\mathrm{Na}_{2} \mathrm{CO}_{3}(2 \mathrm{M})(99 \%$ Merck) was added dropwise to the mixed of nitrate solutions with stirring while the temperature was maintained at $70{ }^{\circ} \mathrm{C}$ until $\mathrm{pH}=9.7 \pm 0.1$ was achieved. The resulting precipitate was then left in these conditions for $2 \mathrm{~h}$. The aged suspension was filtered and then washed several times with warm distilled water until no further $\mathrm{Na}^{+}$was observed in the washings [28], as tested by flame atomic adsorption. The precipitate was then dried in an oven at the range of temperature and time to give a material denoted as the catalyst precursor, which was subsequently calcined in static air in a furnace at $600{ }^{\circ} \mathrm{C}$ for $6 \mathrm{~h}$ to obtain the final catalyst.

\subsection{Catalysts characterization}

\subsubsection{X-Ray Diffraction (XRD)}

XRD analysis technique was used to determine the crystalline phases present in the precursor and calcined supported Fe-Co-Mn catalysts (before and after the test). The catalyst specimen was loaded on a sample holder; all samples analyzed on a Bruker AXS D8 Advance diffractometer using monochromatized $\mathrm{Cu}$-Karadiation at $40 \mathrm{kV}, 30 \mathrm{~mA}$, selecting a scan range of $4^{\circ}<2 \theta<70^{\circ}$. Different present 
phases were identified by matching experimental patterns to entries in Diffract plus version 6.0 indexing software.

\subsubsection{BET measurements}

BET surface areas, pore volumes and average pore sizes of the catalyst precursor and calcined samples (before and after the test) were measured by $\mathrm{N}_{2}$ physisorption using a Quantachrome Nova 2000 automated system (USA). Each catalyst sample was degassed under nitrogen atmosphere at $300{ }^{\circ} \mathrm{C}$ for $3 \mathrm{~h}$. In order to obtain the BET surface areas, pore volumes and average pore sizes, different samples were evacuated at $-196{ }^{\circ} \mathrm{C}$ for 66 minutes.

\subsubsection{Thermal Gravimetric Analysis (TGA) and Differential Scanning Calorimetry (DSC)}

The weight changes in the catalyst precursor were measured using TGA/DSC simultaneous thermal analyzer (model 1500+, Rheometric Scientific) under a flow of dry air. The temperature was raised from room temperature to $600{ }^{\circ} \mathrm{C}$ using a linear programmer at heating rate of $10^{\circ} \mathrm{C}$ per min. The sample weight was between 15 and $20 \mathrm{mg}$.

\subsubsection{Scanning Electron Microscopy (SEM) and} Energy Dispersive x-ray Spectrometer (EDS)

The morphology of the catalysts and their precursors was observed by means of a Cambridge S-360 scanning electron microscope instrument (made in England) operating at 20 $\mathrm{KV}$ coupled to an energy dispersive $\mathrm{x}$-ray spectrometer (EDS). The samples were coated with gold/palladium for $80 \mathrm{~s}$ in $20 \mathrm{~s}$ intervals before the measurements to avoid charging problems.

\subsubsection{Temperature Programmed Reduction} (TPR)

TPR measurements were carried out using a Micrometrics TPD/TPR 2900 system. The TPR experiment was performed to determine the reducibility of the surface of calcined catalyst before the test. The sample $(0.1 \mathrm{~g})$ was put in a quartz reactor and pretreatment in a He flow ( $40 \mathrm{ml} / \mathrm{min}$ ) up to $300{ }^{\circ} \mathrm{C}$ and kept for $30 \mathrm{~min}$ to remove the adsorbed water and other contaminants followed by cooling to $25^{\circ} \mathrm{C}$. The reducing gas containing $5 \% \mathrm{H}_{2}$ in $\mathrm{Ar}(40 \mathrm{ml} / \mathrm{min})$ was passed over the sample with the heating rate of $10^{\circ} \mathrm{C} / \mathrm{min}$ from ambient to $1000{ }^{\circ} \mathrm{C}$ for 2 $\mathrm{h}$, while monitoring the $\mathrm{H}_{2}$ uptake by a thermal conductivity detector (TCD). Calibration of the $\mathrm{H}_{2}$ uptake was done by reduction of $\mathrm{CuO}$ powder.

\subsection{Catalyst testing}

Figure 1 indicates the schematic lay out of experimental setup. The dichotomous stainless steel single tubular vertical fixed bed micro reactor was used; the length of the tube was 360 $\mathrm{mm}$ with inner diameter of $20 \mathrm{~mm}$. the reactor is mounted inside a tubular furnace (Atbin, Model ATU 150-15) capable of producing temperature up to $1500{ }^{\circ} \mathrm{C}$ and controlled by a digital programmable controller (DPC). The alumina jacket is surrounded the tubular micro reactor in order to provide a uniform wall temperature along the length of the reactor.

Preheating zone ahead of the catalyst packing and also the beneath zone of the catalyst bed were filled with inert quartz glass beads. The required amount of catalyst $(1.0 \mathrm{~g})$ was held in the middle of the reactor using quartz wool. An electronic back pressure regulator was used, which can control the total pressure of the desired process using a remote control via integration with the TESCOM software package, which can improve or modify its efficiency; it is capable of working on pressures ranging from atmospheric pressure to $100 \mathrm{bar}$.

The temperature of all of different zones include: preheating zone, catalyst bed and underneath zone of the reactor is checked by three separate thermocouples placed in different parts of the reactor. The thermocouple which controls bed temperature is placed exactly below the catalyst bed. The inlet feed gas is arrived from top of the reactor and the outlet products are avoided from underside of the reactor. Three mass flow controllers (Brooks, Model 5850E) equipped with a four-channel read out and control equipment (Brooks 0154) were used to adjust automatically the flow rate of the inlet gases $\left(\mathrm{CO}, \mathrm{H}_{2}\right.$, and $\mathrm{N}_{2}$ with purity of $99.999 \%)$. The catalytic reactor bed was purged by nitrogen gas and then the reduction process was carried out at atmospheric pressure under a flowing $\mathrm{H}_{2}-\mathrm{N}_{2}$ stream $\left(\mathrm{H}_{2} / \mathrm{N}_{2}=1\right.$, flow of each gas $=30 \mathrm{~mL} / \mathrm{min})$ at $400{ }^{\circ} \mathrm{C}$ for 12 $\mathrm{h}$ before synthesis gas exposure. The $\mathrm{CO}$ hydrogenation reaction was carried out under process conditions of $\mathrm{T}=350^{\circ} \mathrm{C}, \mathrm{P}=1 \mathrm{bar}, \mathrm{H}_{2} / \mathrm{CO}=$ $2 / 1$ and GHSV $=4500 \mathrm{~h}^{-1}$. Reactant and product streams were analyzed on-line using a gas chromatograph (Thermo ONIX UNICAM PROGC+) equipped with sample loop, two Thermal Conductivity Detectors (TCD) and one Flame Ionization Detector (FID) able to perform the analysis of a wide variety of gaseous hydrocarbon mixtures, one TCD used for the analysis of hydrogen and the other one used for all the permanent gases, such as: $\mathrm{N}_{2}, \mathrm{O}_{2}$ and 
CO. The FID is used for the analysis of hydrocarbons. The system is applicable to the analysis of non-condensable gases, methane through $\mathrm{C}_{8}$ hydrocarbons. The contents of the sample loop were injected automatically into an alumina capillary column $(30 \mathrm{~m} \times 0.550 \mathrm{~mm})$. Helium was employed as a carrier gas for optimum sensitivity (flow rate $=30 \mathrm{~mL} / \mathrm{min}$ ). The GC calibration was carried out using various calibration mixtures and pure compounds obtained from American Matheson Gas Company (USA).

The results in terms of $\mathrm{CO}$ conversion and selectivity of products are given at each space velocity. The CO conversion (\%) is calculated according to the normalization method:

CO conversion $(\%)=\frac{\left(\text { Moles of } C O_{\text {in }}\right)-\left(\text { Moles of } \mathrm{CO}_{\text {out }}\right)}{\text { Moles of } \mathrm{CO}_{\text {in }}} \times 100$
The selectivity (\%) towards the individual components on carbon-basis is calculated according to the same principle:

Selectivity of product $(\%)=\frac{\text { moles of carbonin product }}{\text { moles of converted } C O} \times 100$

Molar flow rate of carbon monoxide in feed is calculated by:

$$
F_{C O}^{o}=v^{o} C_{C O}=\frac{v^{o} P_{C O}}{R T}
$$

where, $\mathrm{Fo}^{\circ} \mathrm{CO}$ represents inlet molar flow of $\mathrm{CO}$ $\left(\right.$ mol.min $\left.{ }^{-1}\right), v^{o}$ denotes volumetric flow rate of input gas (mL.min-1), CCo represents concentration of $\mathrm{CO}(\mathrm{mol} / \mathrm{mL}), P_{C O}$ represents partial pressure of $\mathrm{CO}$ (bar), $T$ denotes gas temperature $(\mathrm{K})$, and $R$ denotes universal gas constant (mL. bar. $\left.\mathrm{mol}^{-1} \cdot \mathrm{K}^{-1}\right)$.

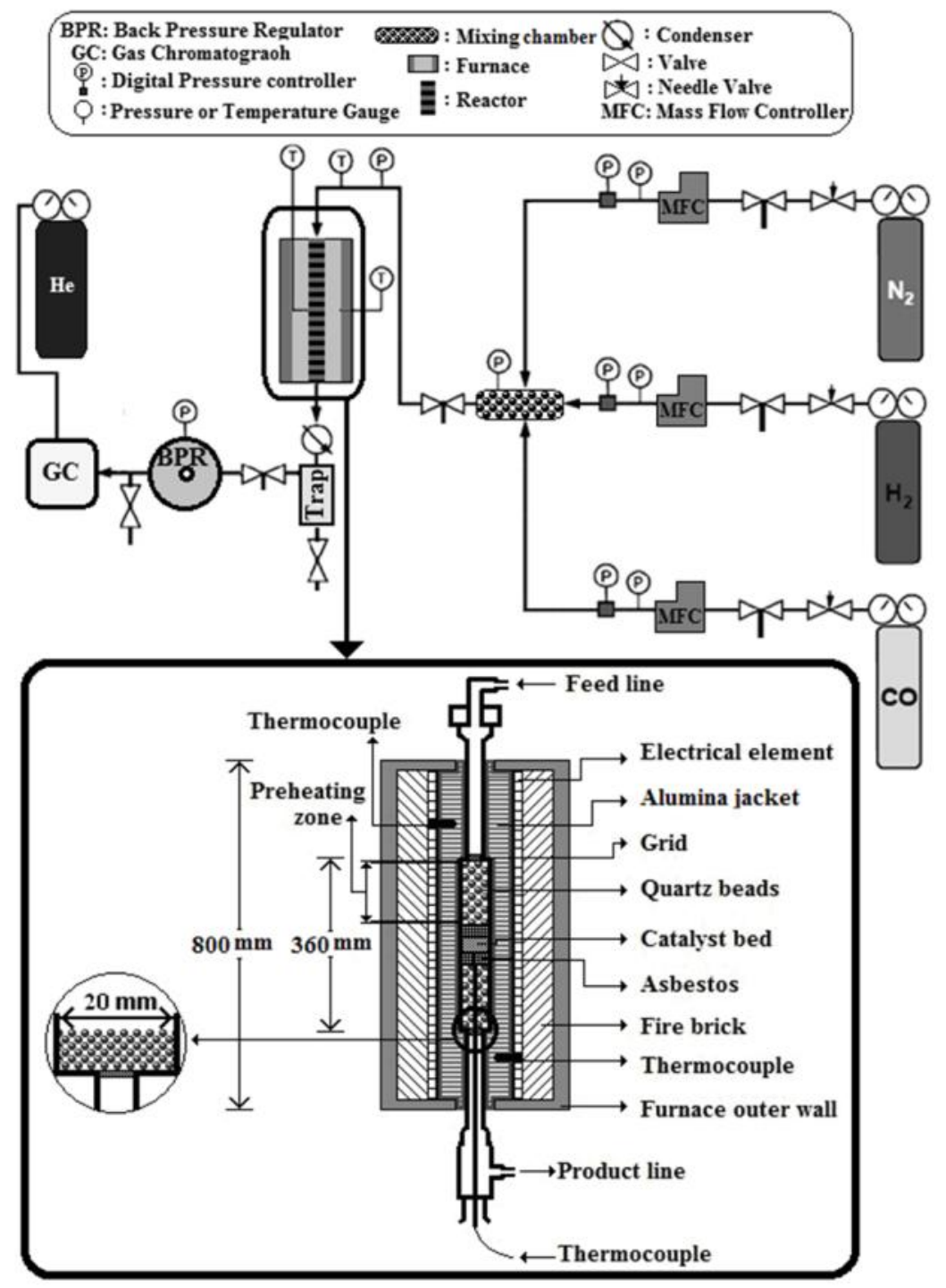

Figure 1. Schematic representation of the reactor in a flow diagram used 
To calculate consumption rate of $\mathrm{CO}$, equation of differential reactor is used [29,30]. Consequently the equation of plug reactor changed as follows:

$$
\begin{aligned}
& \frac{W_{c a t}}{F_{C O}^{o}}=\int_{X_{C O, \text { in }}}^{X_{C O \text { out }}} \frac{d X_{C O}}{-r_{C O}}=\frac{1}{\left(-r_{C O}\right)_{a v g}} \int_{X_{C O \text {, in }}}^{X_{C O \text { out }}} d X_{C O}=\frac{X_{C O, \text { out }}-X_{C O, \text { in }}}{\left(-r_{C O}\right)_{a v g}} \\
& \left(-r_{C O}\right)_{\text {avg }}=\frac{F_{C O}^{o}\left(X_{C O, \text { out }}-X_{C O \text {, in }}\right)}{W_{c a t}}=\frac{F_{C O, \text { in }}-F_{C O, \text { out }}}{W_{\text {cat }}}
\end{aligned}
$$

Therefore as a brief:

$$
\frac{W_{c a t}}{F_{C O}^{o}}=\frac{X_{C O}}{-r_{C O}}
$$

and hence:

$$
-r_{C O}=\frac{X_{C O} F_{C O}^{o}}{W_{c a t}}
$$

\section{Results and Discussion}

\subsection{Effect of drying conditions}

In the catalyst preparation via precipitation methods drying of the obtained precipitate is one of the main steps of catalyst preparation. Drying manner (in view point of drying time and temperature) leads to various structure, texture, porosity, surface area, morphology of the final catalyst and also affect the reduction behavior of the catalyst, this subject leads to different catalytic performance of the catalyst for $\mathrm{CO}$ hydrogenation. In the present work we attempt to investigate the effect of drying time and temperature of the catalyst precursor on the catalytic behavior of the Fe-Co- $\mathrm{Mn} / \mathrm{MgO}$ ternary catalyst for $\mathrm{CO}$ hydrogenation and also on the structural properties of the precursor and final calcined catalysts. The optimum dry- ing conditions were identified with respect to the activity for the conversion of synthesis gas into light olefins. The precursor drying conditions affect the catalytic performance of the final catalyst and hence affect the CO consumption rate and other surface reactions rate over this catalyst.

\subsubsection{Effect of drying time}

In order to investigate the effect of precipitate drying time on the catalytic performance and structure of the final catalyst, a series of the obtained $\mathrm{Fe}-\mathrm{Co}-\mathrm{Mn} / \mathrm{MgO}$ precipitates which were drying at $120{ }^{\circ} \mathrm{C}$ for different times between 8-24 h were prepared. In order to obtain the fresh calcined catalysts all of these dried precursors were calcined at $600{ }^{\circ} \mathrm{C}$ for $6 \mathrm{~h}$ under air atmosphere. The obtained catalysts were evaluated for $\mathrm{CO}$ hydrogenation under the same operational conditions $\left(\mathrm{T}=350{ }^{\circ} \mathrm{C}, \mathrm{P}\right.$ $=1 \mathrm{~atm}, \mathrm{H}_{2} / \mathrm{CO}=2 / 1$, and $\mathrm{GHSV}=5400 \mathrm{~h}^{-1}$ ) [26]; the obtained results are presented in Figure 2. As it can be seen, fresh catalyst obtained from the precursor which dried at 120 ${ }^{\circ} \mathrm{C}$ for $16 \mathrm{~h}$ has shown the best catalytic performance for $\mathrm{CO}$ hydrogenation. Characterization of all of these catalyst precursors and calcined sample (fresh and used) was carried out using powder x-ray diffraction and the obtained XRD patterns are displayed in Figure 3; as it can be observed all of the catalyst precursors were found to be amorphous and the presented phases in all of them were undetectable. All precursors after the calcination process have shown the same XRD patterns and all of them are comprised of the same phases, including: $\mathrm{Fe}_{2} \mathrm{O}_{3}$ (rhombohedral), $\mathrm{CoFe}_{2} \mathrm{O}_{4}$ (cubic), $\mathrm{Co}_{3} \mathrm{O}_{4}$ (cubic), $\mathrm{CoMnO}_{4}$ (cubic), $\mathrm{Fe}_{3} \mathrm{O}_{4}$ (cubic), and $\mathrm{Mn}_{2} \mathrm{O}_{3}$ (cubic). All of the tested catalysts

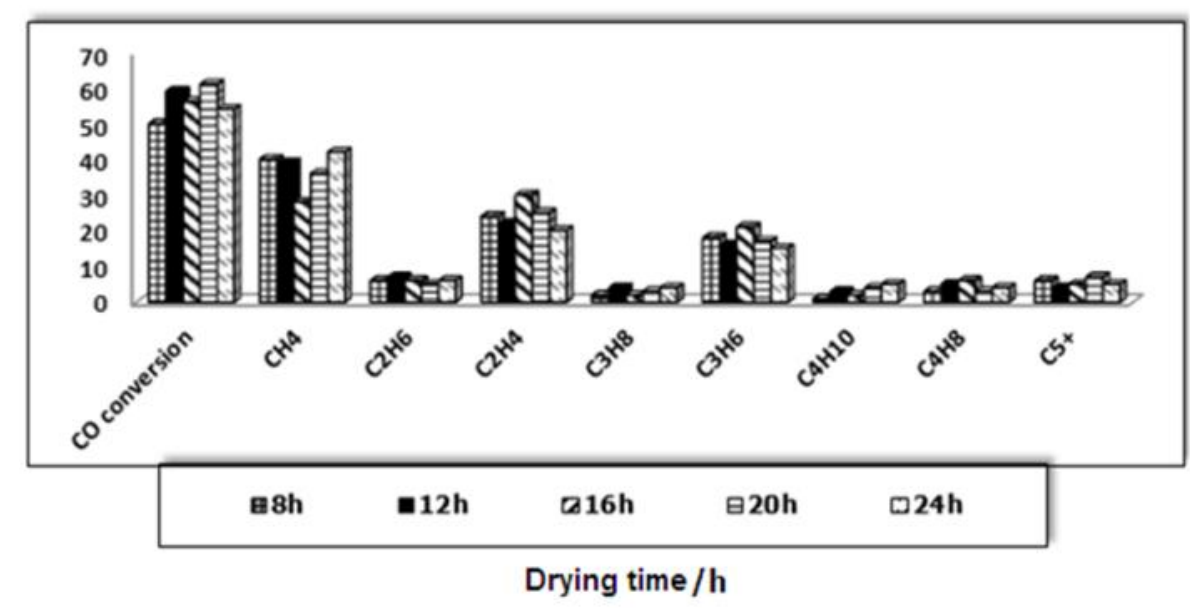

Figure 2. Effect of precursor drying time on the catalytic performance of Fe-Co-Mn/MgO catalyst 
were characterized using XRD technique and the same phases of $\mathrm{CoO}$ (cubic), $\mathrm{MnO}$ (cubic), $\mathrm{FeO}$ (cubic), $\mathrm{Fe}_{2} \mathrm{C}$ (monoclinic), $\mathrm{Fe}$ (cubic), Co (cubic), and $\mathrm{C}$ (hexagonal), were identified in all of used samples. BET technique was used in order to investigate the physical structure of the precursor and calcined catalyst (before and after the test) and the specific surface areas, pore volumes and pore sizes of these samples are presented in Table 1 . BET results showed that the prepared catalysts have different porosity and surface areas in the precursor and calcined (fresh and used) cases. The obtained results show that precursor samples have the highest specific surface area and calcination process leads to decrease in the specific surface area of the fresh calcined samples (Table 1).

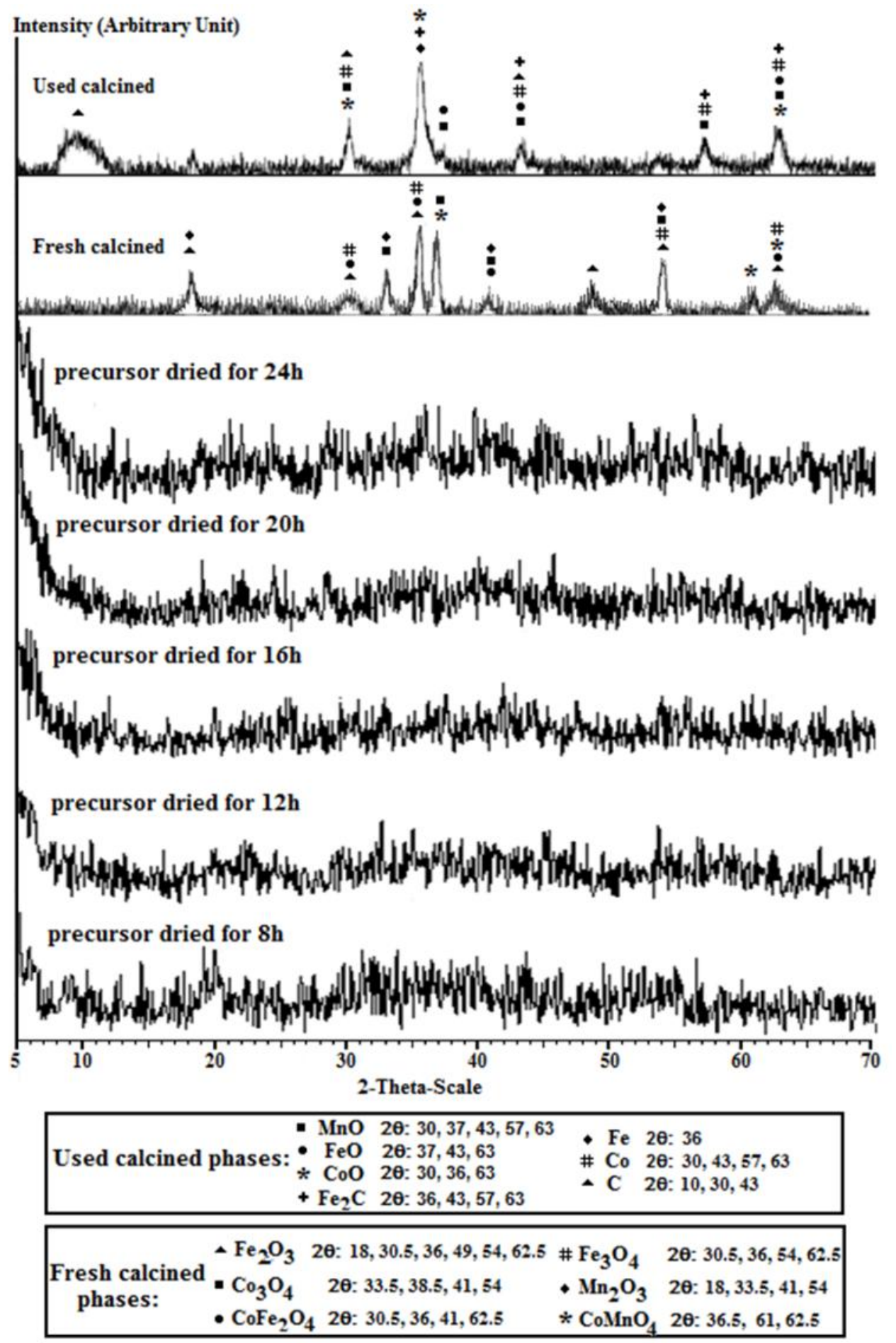

Figure 3. The XRD patterns of the precursors and calcined samples (fresh and used) of the Fe-Co$\mathrm{Mn} / \mathrm{MgO}$ 
The specific surface area of the catalyst is one of the main factors for the better catalytic performance but this is not the only determinative factor; as it can be seen in Table 1 the catalyst obtained from the precursor dried for $16 \mathrm{~h}$ has high specific surface area. After CO hydrogenation reaction over the catalyst surface the specific surface area of the used samples are slightly decreased. The BET results also showed that along with increasing the precursor drying time the specific surface area of the precursors and calcined samples (fresh and used) were increased. Table 1 results also showed that pore size and pore volumes of all samples have shown increasing trend along with increasing precursor drying time.

In order to investigate the effect of drying time of catalyst precursor on the morphological and textural properties of the precursor and calcined catalysts (before and after the test) all of them were characterized using scanning electron microscopy technique. The obtained SEM images are presented in Figures 4-6. Figure 4 shows the SEM images of the catalyst precursors which dried for different time; as it can be seen the catalyst precursor which dried for $16 \mathrm{~h}$ has different morphology and agglomerate (Figure 4c); this sample is comprised of very fine grains with high agglomeration adhesive to each other and also greater particles with undefined geometric shapes are observed in this sample texture. The SEM images of the other precursors have shown the same morphological features and all of them are comprised of small spherical particles with medium agglomeration. After calcination process the morphology of the calcined samples were investigated using SEM and the obtained electron micrographs are illustrated in Figure 5. As it can be observed the calcined sample obtained from the precursor which dried for $16 \mathrm{~h}$ has different morphological feature; this sample is comprised of the spherical grains with various sizes with low dense agglomerate. The other fresh calcined samples have shown similar morphology and textural properties and have more sticky texture than the optimum sample (Figure 5c) this point can affect the reduction behavior of the catalyst (as it will be observed in TPR results) and consequently affect the catalytic performance for CO hydrogenation.

The morphological properties of the tested catalysts also were investigated using SEM and the obtained images are presented in Figure 6; this figure shows that the morphology of the tested samples is completely different from the fresh catalysts and all of them have uneven and disproportionate agglomeration and comprised of larger particles with different sizes and geometric shapes. As can be seen, in the used samples the particles are more adhesive to each other and constitute large agglomerate in their texture, this point leads to decrease in the surface area in the tested samples (As reported in Table 1).

The EDS technique was used in order to investigate and determine the mean element proportions of the catalyst with the best catalytic performance in the cases of precursor and calcined (before and after the test). The obtained EDS results are reported in Table 2 and the EDS spectra of the samples are displayed in Figure 7. As it shown, the catalyst precursor is comprised of $\mathrm{N}, \mathrm{C}, \mathrm{O}, \mathrm{Mg}, \mathrm{Fe}, \mathrm{Mn}$, and Co elements (Figure 7 and Table 2). These elements are referred to presence of the hydroxyl, nitrate and carbonate compounds in the precursor sample which amorphous phases makes unde-

Table 1. The BET results of the catalysts with different precursor drying times in the cases of precursor, fresh and used

\begin{tabular}{|c|c|c|c|c|c|c|c|c|c|}
\hline \multirow{2}{*}{$\begin{array}{l}\text { Catalyst } \\
\text { drying } \\
\text { time }\end{array}$} & \multicolumn{3}{|c|}{ Precursor } & \multicolumn{3}{|c|}{$\begin{array}{c}\text { Fresh } \\
\text { calcined }\end{array}$} & \multicolumn{3}{|c|}{$\begin{array}{c}\text { Used } \\
\text { calcined }\end{array}$} \\
\hline & $\begin{array}{c}\mathrm{SSA} \\
\left(\mathrm{m}^{2} / \mathrm{g}\right)\end{array}$ & $\mathrm{PV}\left(\mathrm{cm}^{3} / \mathrm{g}\right)$ & $\begin{array}{l}\mathrm{PS} \\
\left(\mathrm{A}^{\circ}\right)\end{array}$ & $\begin{array}{c}\mathrm{SSA} \\
\left(\mathrm{m}^{2} / \mathrm{g}\right)\end{array}$ & $\begin{array}{c}\mathrm{PV} \\
\left(\mathrm{cm}^{3} / \mathrm{g}\right)\end{array}$ & $\begin{array}{l}\mathrm{PS} \\
\left(\mathrm{A}^{\circ}\right)\end{array}$ & $\begin{array}{c}\mathrm{SSA} \\
\left(\mathrm{m}^{2} / \mathrm{g}\right)\end{array}$ & $\begin{array}{c}\mathrm{PV} \\
\left(\mathrm{cm}^{3} / \mathrm{g}\right)\end{array}$ & $\begin{array}{l}\mathrm{PS} \\
\left(\mathrm{A}^{\circ}\right)\end{array}$ \\
\hline $8 \mathrm{~h}$ & 133.14 & $4.79 \times 10^{-2}$ & 22.68 & 82.68 & $1.12 \times 10^{-2}$ & 22.48 & 80.43 & $1.23 \times 10^{-2}$ & 21.33 \\
\hline $12 \mathrm{~h}$ & 139.98 & $5.04 \times 10^{-2}$ & 23.00 & 90.14 & $1.01 \times 10^{-2}$ & 22.13 & 87.34 & $1.31 \times 10^{-2}$ & 22.47 \\
\hline $16 \mathrm{~h}$ & 147.00 & $5.75 \times 10^{-2}$ & 22.75 & 99.22 & $1.15 \times 10^{-2}$ & 23.00 & 96.12 & $1.30 \times 10^{-2}$ & 22.96 \\
\hline $20 \mathrm{~h}$ & 160.21 & $6.23 \times 10^{-2}$ & 23.41 & 107.14 & $1.38 \times 10^{-2}$ & 24.78 & 102.99 & $1.52 \times 10^{-2}$ & 24.01 \\
\hline $24 \mathrm{~h}$ & 169.42 & $6.58 \times 10^{-2}$ & 25.01 & 115.26 & $1.45 \times 10^{-2}$ & 24.93 & 112.61 & $1.69 \times 10^{-2}$ & 24.12 \\
\hline
\end{tabular}

SSA: Specific Surface area; PV: Pore volume; PS: Pore Size 


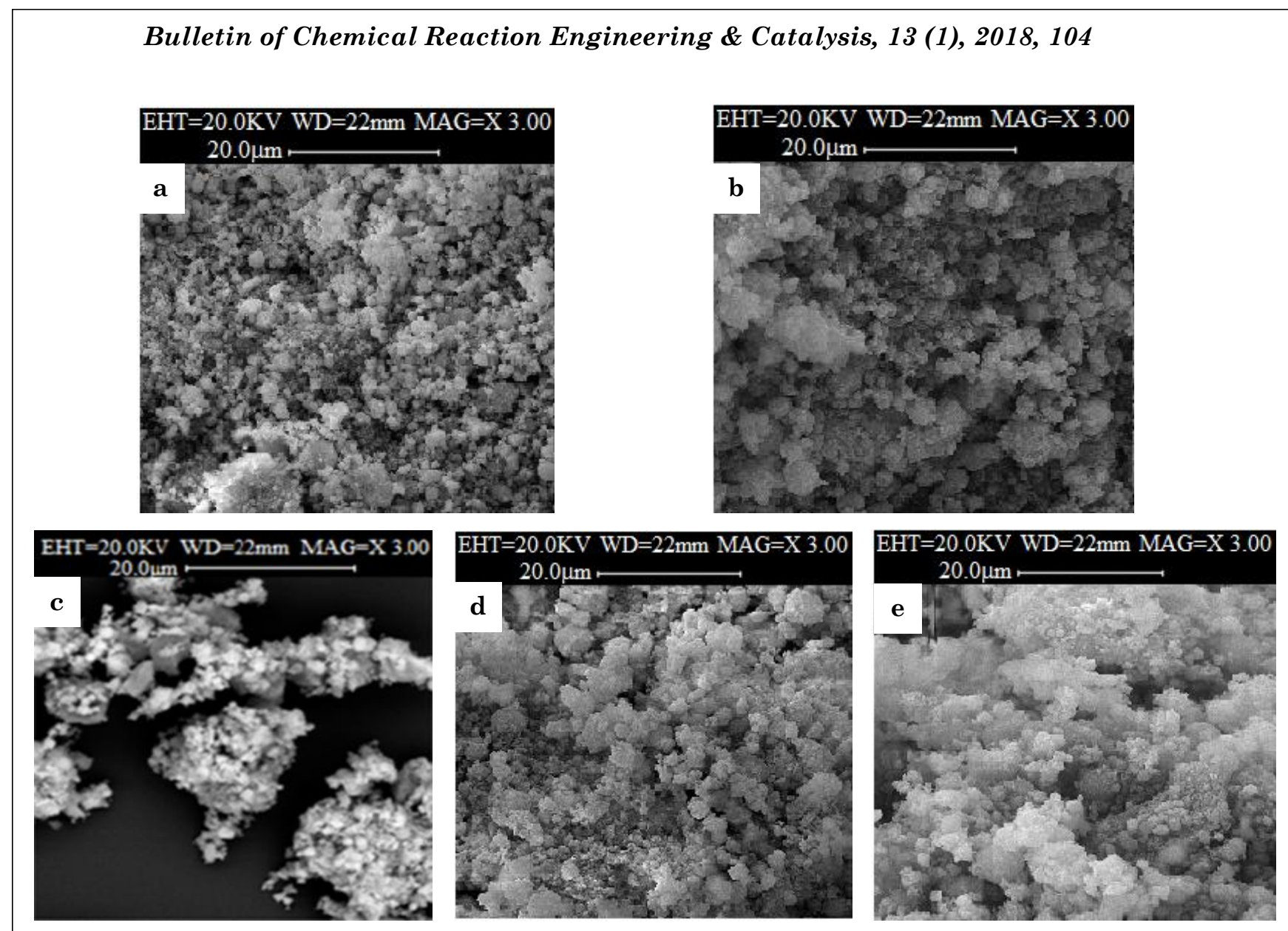

Figure 4. The SEM images of the catalyst precursors dried for (a) $8 \mathrm{~h}$, (b) $12 \mathrm{~h}$, (c) $16 \mathrm{~h}$, (d) $20 \mathrm{~h}$, and (e) $24 \mathrm{~h}$.
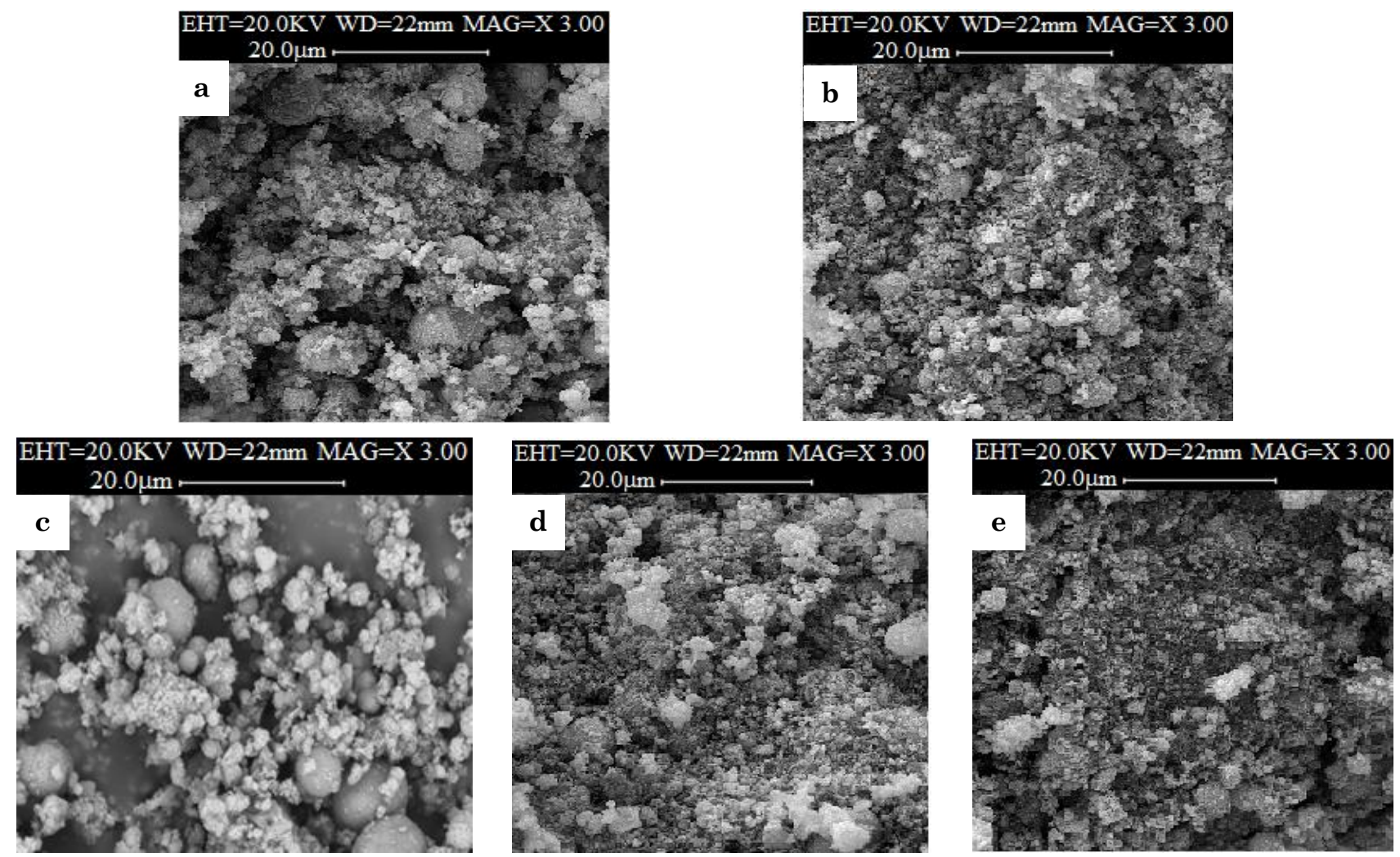

Figure 5. The SEM images of the fresh calcined catalyst obtained from precursors dried for (a) $8 \mathrm{~h}$, (b) $12 \mathrm{~h}$, (c) $16 \mathrm{~h},(\mathrm{~d}) 20 \mathrm{~h}$, and (e) $24 \mathrm{~h}$ 
tectable these phases by x-ray diffraction. The EDS spectrum of the calcined sample before the test shows different elements of $\mathrm{O}, \mathrm{Mg}, \mathrm{Fe}$, $\mathrm{Mn}$, and Co (Figure $7 \mathrm{~b}$ and Table 2); presence of these elements confirms that the fresh calcined sample is comprised of different oxidic phases of iron, cobalt and manganese elements. The XRD results also confirm and support the presence of various oxidic phases in the fresh sample. The used catalyst EDS spectrum refers to presence of $\mathrm{C}, \mathrm{O}, \mathrm{Mg}, \mathrm{Fe}, \mathrm{Mn}$, and Co elements (Figure 7c and Table 2). Presence of these elements in the used sample is in agreement with the XRD results and confirms the presence of various oxidic and carbide phases in the used sample.

In order to investigate the effect of precursor drying time on the reduction behavior of the obtained catalysts all of the fresh calcined catalysts were characterized using $\mathrm{H}_{2}$-TPR technique. The obtained TPR profiles are presented in Figure 8; these calcined samples showed four distinguished reduction peaks. The XRD results showed the presence of various oxidic phases of $\mathrm{Co}_{3} \mathrm{O}_{4}, \mathrm{Fe}_{2} \mathrm{O}_{3}, \mathrm{Fe}_{3} \mathrm{O}_{4}$, and $\mathrm{Mn}_{2} \mathrm{O}_{3}$ in the fresh catalyst (Figure 3); the $\mathrm{Co}_{3} \mathrm{O}_{4}$ phase is reduced according to the following reactions and steps [31,32]:

$$
\begin{aligned}
& \mathrm{Co}_{3} \mathrm{O}_{4}+\mathrm{H}_{2} \rightarrow 3 \mathrm{CoO}+\mathrm{H}_{2} \mathrm{O} \\
& 3 \mathrm{CoO}+3 \mathrm{H}_{2} \rightarrow 3 \mathrm{Co}^{\circ}+3 \mathrm{H}_{2} \mathrm{O}
\end{aligned}
$$

The first and second peaks (peak A and B) in all TPR profiles are referred to these reduction steps and correspond to the reduction of $\mathrm{Co}_{3} \mathrm{O}_{4}$ to $\mathrm{Co}^{\circ}$ phase. During these two reduction peaks $\mathrm{Co}^{+3}$ and $\mathrm{Co}^{+2}$ oxide species are reduced to metallic cobalt. The iron oxidic phases $\left(\mathrm{Fe}_{2} \mathrm{O}_{3}\right.$ - and $\left.\mathrm{Fe}_{3} \mathrm{O}_{4}\right)$ are reduced metallic iron according to the following steps [33,34]:

$$
\begin{aligned}
& 3 \mathrm{Fe}_{2} \mathrm{O}_{3}+\mathrm{H}_{2} \rightarrow 2 \mathrm{Fe}_{3} \mathrm{O}_{4}+\mathrm{H}_{2} \mathrm{O} \\
& 2 \mathrm{Fe}_{3} \mathrm{O}_{4}+\mathrm{H}_{2} \rightarrow 6 \mathrm{FeO}+2 \mathrm{H}_{2} \mathrm{O} \\
& 6 \mathrm{FeO}+6 \mathrm{H}_{2} \rightarrow 6 \mathrm{Fe}+6 \mathrm{H}_{2} \mathrm{O}
\end{aligned}
$$

The peak $\mathrm{C}$ (third reduction peak) in the TPR profiles of the catalysts is allocated to reduction of $\mathrm{Fe}_{2} \mathrm{O}_{3}$ to $\mathrm{Fe}_{3} \mathrm{O}_{4}$ and $\mathrm{Fe}_{3} \mathrm{O}_{4}$ to $\mathrm{FeO}$ it has been reported that $\mathrm{FeO}$ is the main important intermediate during the reduction of oxidic iron to iron [35] although $\mathrm{FeO}$ is not stable in air. The fourth reduction peak (peak D) in the TPR profiles is attributed to final reduction step of $\mathrm{FeO} \rightarrow \mathrm{Fe}$ and $\mathrm{Mn}_{2} \mathrm{O}_{3} \rightarrow \mathrm{MnO}$ [36-38]. The TPR profiles presented in Figure 8 showed
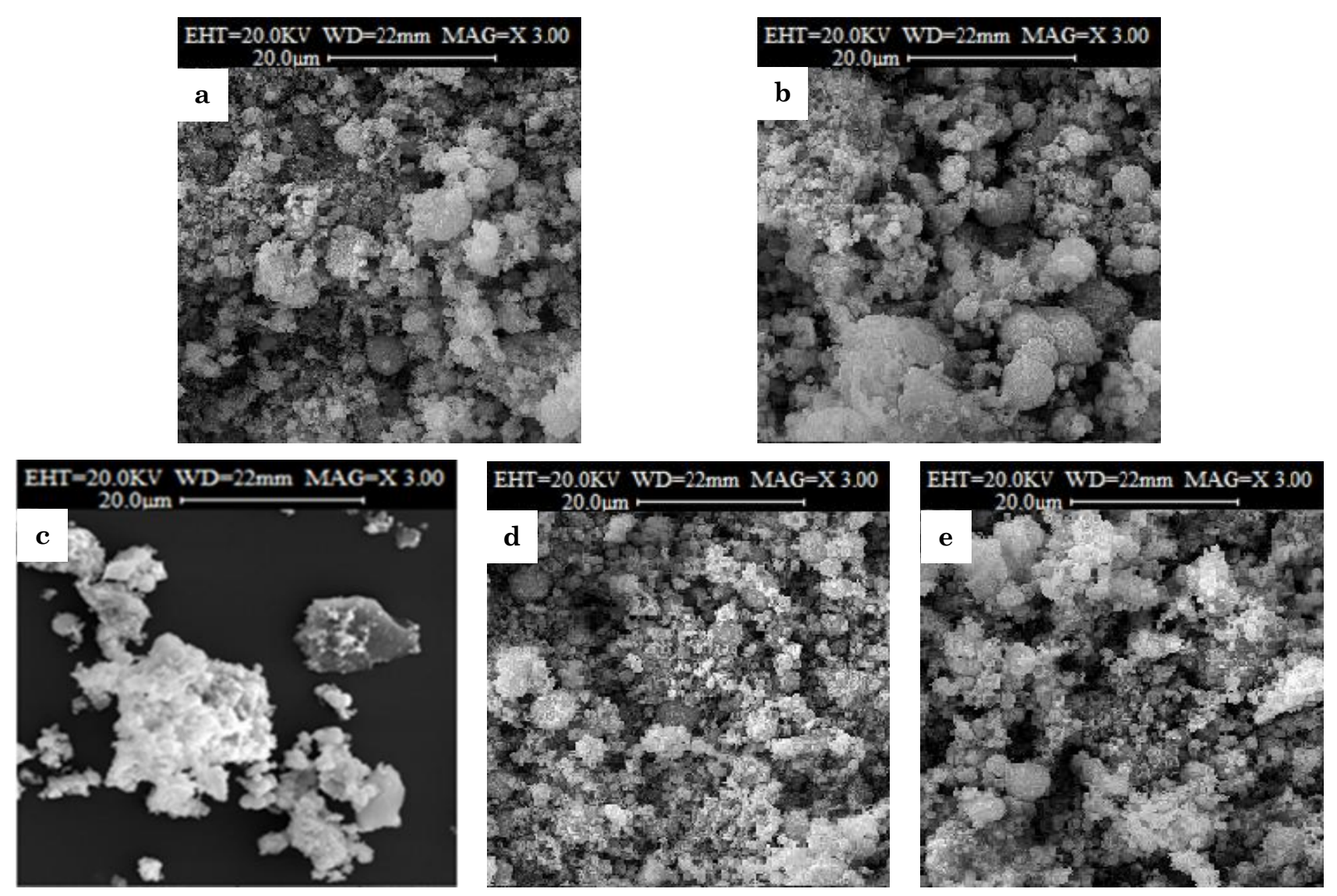

Figure 6. The SEM images of the used calcined catalyst obtained from precursors dried for (a) $8 \mathrm{~h}$, (b) $12 \mathrm{~h}$, (c) $16 \mathrm{~h}$, (d) $20 \mathrm{~h}$, and (e) $24 \mathrm{~h}$ 


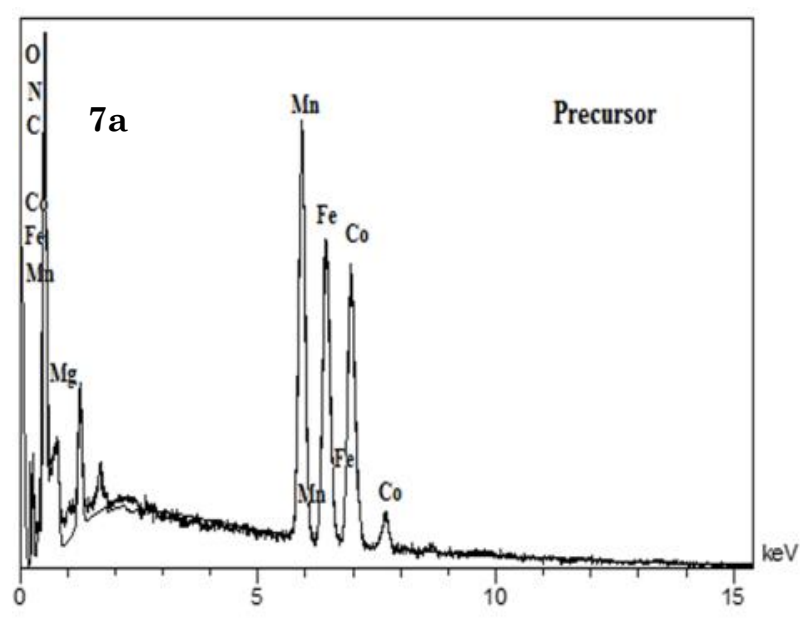

the same reduction peaks and steps; this figure also showed that reduction process of the calcined samples obtained from the precursor dried for $16 \mathrm{~h}$ started at lower temperature and ended at lower temperature in comparison with the other calcined catalysts. On the other word for this catalyst the reduction process is carried out more easily than the other samples; this point supports the better catalytic performance for this sample.

Since the variation of the precursor drying time affect and changed the $\mathrm{CO}$ conversion consequently according to the equation 7 $\left(-r_{C O}=X_{C O} \cdot F^{\circ} \mathrm{CO} / W_{c a t}\right)$ the $\mathrm{CO}$ consumption rates
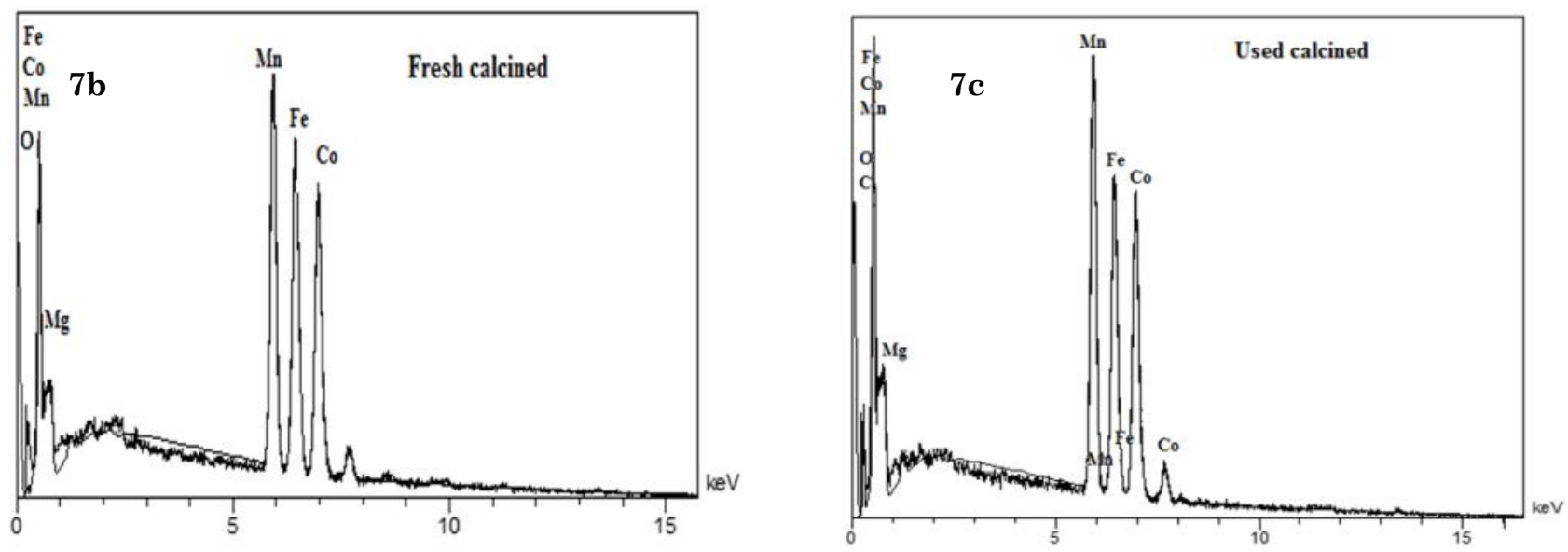

Figure 7. EDS spectrums of Fe-Co-Mn/MgO catalyst with precursor drying time of $16 \mathrm{~h}$ in (a) precursor, (b) fresh calcined, and (c) used calcined cases

Table 2. EDS data of Fe-Co-Mn/MgO catalyst with precursor drying time of $16 \mathrm{~h}$

\begin{tabular}{lccc}
\hline Catalyst & Elements & Weight (\%) & Atomic (\%) \\
\hline Precursor & $\mathrm{C}$ & 12.79 & 23.74 \\
& $\mathrm{~N}$ & 3.74 & 5.95 \\
& $\mathrm{O}$ & 35.67 & 49.67 \\
& $\mathrm{Mg}$ & 3.48 & 3.19 \\
& $\mathrm{Mn}$ & 15.29 & 5.24 \\
& $\mathrm{Fe}$ & 13.13 & 6.01 \\
\hline Calcined catalyst (before the & $\mathrm{Co}$ & 15.90 & 45.92 \\
test) & $\mathrm{O}$ & 20.85 & 8.44 \\
& $\mathrm{Mg}$ & 5.82 & 15.35 \\
& $\mathrm{Mn}$ & 23.93 & 14.64 \\
& $\mathrm{Fe}$ & 23.20 & 15.66 \\
\hline Calcined catalyst (after the test) & $\mathrm{Co}$ & 26.19 & 31.93 \\
& $\mathrm{C}$ & 15.53 & 40.48 \\
& $\mathrm{O}$ & 26.22 & 3.79 \\
& $\mathrm{Mg}$ & 3.73 & 8.60
\end{tabular}


and also other surface reaction rates (production of methane and hydrocarbon formation) were changed. The effect of precursor drying time on the different surface reaction rates was investigated and the obtained results are plotted in Figure 9. As it shown, along with changes of the precursor drying time the surface reactions rate were changed and the catalysts obtained from precursor dried for $16 \mathrm{~h}$ has the lowest methane formation rate and has high hydrocarbon formation rate in comparison with the other prepared samples.

\subsubsection{Effect of precursor drying temperature}

In order to investigate the effect of precursor drying temperature on the catalytic performance and structure of the final catalyst, a series of the Fe-Co-Mn/MgO catalyst precursors which were dried at various temperatures (100$160{ }^{\circ} \mathrm{C}$ ) for $16 \mathrm{~h}$ were prepared. These precursors were calcined at $600{ }^{\circ} \mathrm{C}$ for $6 \mathrm{~h}$ under air atmosphere; the obtained calcined catalysts were tested for $\mathrm{CO}$ hydrogenation under the

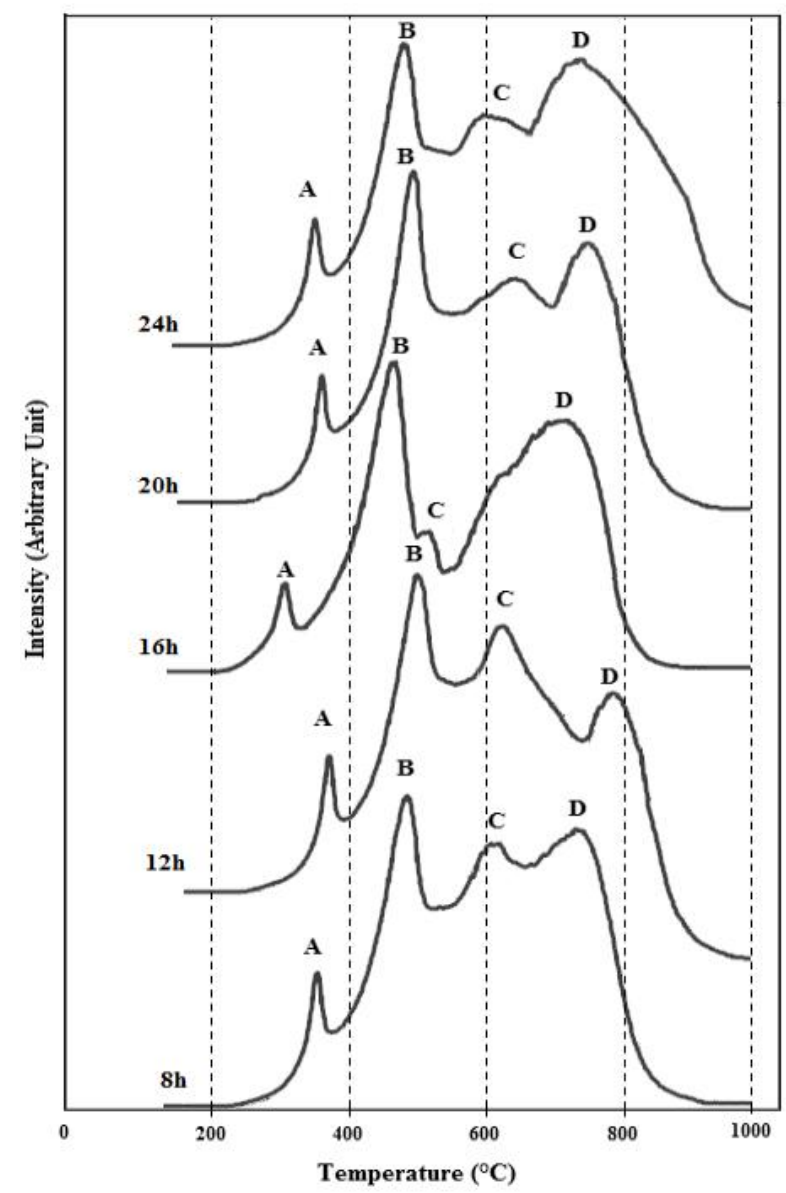

Figure 8. TPR profiles of the Fe-Co- $\mathrm{Mn} / \mathrm{MgO}$ fresh catalysts with different precursor drying times same operational conditions $\left(\mathrm{T}=350^{\circ} \mathrm{C}, \mathrm{P}=1\right.$ atm, $\mathrm{H}_{2} / \mathrm{CO}=2 / 1$, and $\mathrm{GHSV}=5400 \mathrm{~h}^{-1}$ ) [26] and the obtained results are displayed in Figure 10. According to the catalytic behavior results the calcined catalyst obtained from the precursor which dried at $120{ }^{\circ} \mathrm{C}$ for $16 \mathrm{~h}$ has shown the best catalytic performance for production of $\mathrm{C}_{2}-\mathrm{C}_{4}$ light olefins products fraction (this catalyst has higher selectivity toward light olefins and lower selectivity for methane production). All of the fresh calcined samples obtained from the precursor with different drying temperature were characterized using XRD technique and the obtained XRD patterns are presented in Figure 11. It was found that all of them are comprised of the same phases of $\mathrm{Fe}_{2} \mathrm{O}_{3}$ (rhombohedral), $\mathrm{CoFe}_{2} \mathrm{O}_{4}$ (cubic), $\mathrm{Co}_{3} \mathrm{O}_{4}$ (cubic), $\mathrm{CoMnO}_{4}$ (cubic), $\mathrm{Fe}_{3} \mathrm{O}_{4}$ (cubic), and $\mathrm{Mn}_{2} \mathrm{O}_{3}$ (cubic).

In order to investigate the morphological features of the catalyst precursors and calcined samples, all of them were characterized using SEM technique and the obtained electron micrographs are displayed in Figures 12-14. The

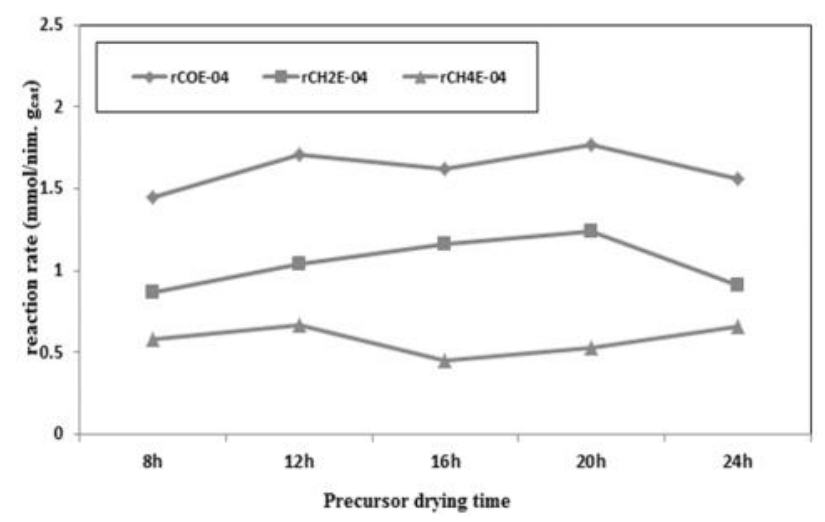

Figure 9. Effect of precursor drying time on different surface reactions rates

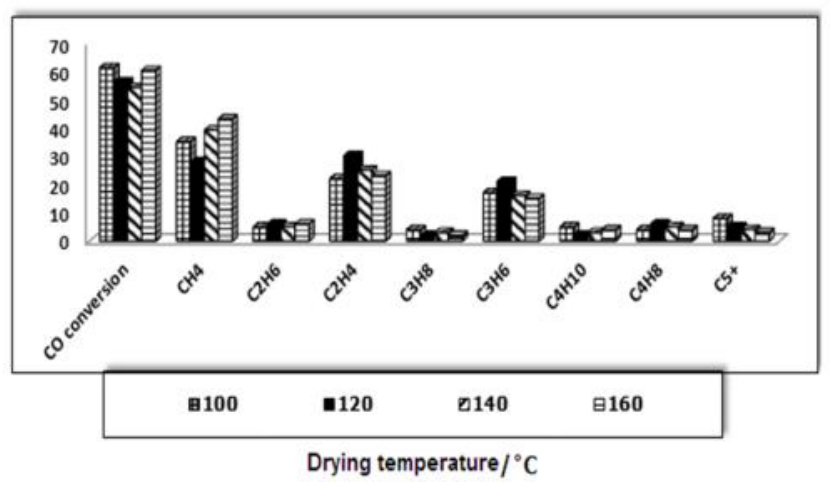

Figure 10. Effect of precursor drying temperature on the catalytic performance of Fe-Co$\mathrm{Mn} / \mathrm{MgO}$ catalyst 
SEM images of the catalyst precursors presented in Figure 12 show that the morphological and textural properties of the precursor which was dried at $120{ }^{\circ} \mathrm{C}$ for $16 \mathrm{~h}$ is different from the other catalyst precursors and comprised of the fine spherical grains particles which adhesive to the larger irregular shape particles. The SEM images of the other precursor almost show the same morphological features and all of them are comprised of the spherical particles with different sizes. After calcination process at $600{ }^{\circ} \mathrm{C}$ for $6 \mathrm{~h}$ the morphology of the obtained calcined samples were investigated using SEM and the obtained electron micrographs are presented in Figure 13; this figure shows that the morphology of the calcined sample obtained from the precursor which dried at $120{ }^{\circ} \mathrm{C}$ for $16 \mathrm{~h}$ is different from the other samples and comprised of spherical grains with various sizes and has low dense agglomerate. The used calcined samples were also characterized using SEM and the obtained
SEM images are illustrated in Figure 14. As it can be seen the morphology of the used samples is different from the fresh samples; the tested catalysts have more adhesive texture and the used sample obtained from precursor which dried at $120{ }^{\circ} \mathrm{C}$ for $16 \mathrm{~h}$ has shown different texture and has high dense agglomerate.

Characterization of the catalyst precursor which dried at $120{ }^{\circ} \mathrm{C}$ for $16 \mathrm{~h}$ was also carried out using TGA and DSC in order to investigate the thermal behavior and the obtained curves are illustrated in Figure 15. This figure shows the catalyst weight loss along with increasing the temperature from ambient to $600{ }^{\circ} \mathrm{C}$ with ramping of $10{ }^{\circ} \mathrm{C} / \mathrm{min}$; it shows a total weight loss of $35 \%$ during unremitting heating process. TGA curve of the catalyst precursor shows three main weight loss steps. The first weight loss step occurs from $60{ }^{\circ} \mathrm{C}$ to $150{ }^{\circ} \mathrm{C}$ is related to the evaporation of the physically adsorbed water in the catalyst pores. The second weight loss step is observed around $180-310^{\circ} \mathrm{C}$ is due

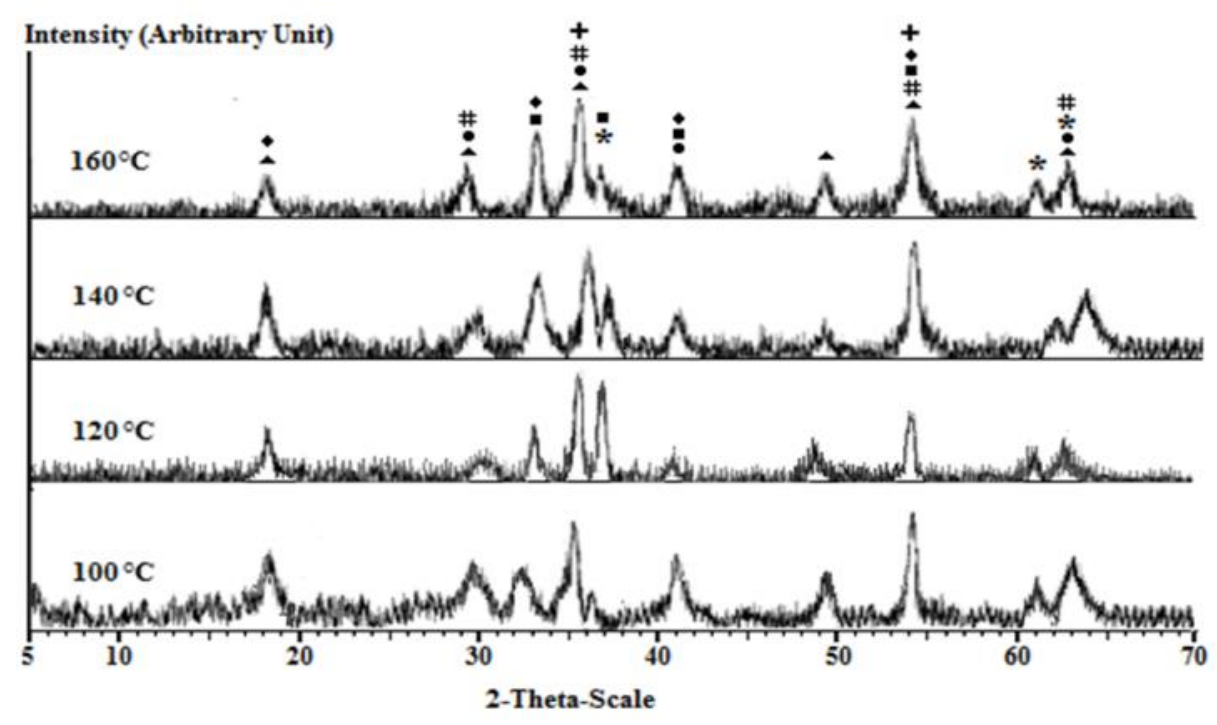

Figure 11. The XRD patterns of the fresh calcined $\mathrm{Fe}-\mathrm{Co}-\mathrm{Mn} / \mathrm{MgO}$ catalyst with different precursor drying temperature
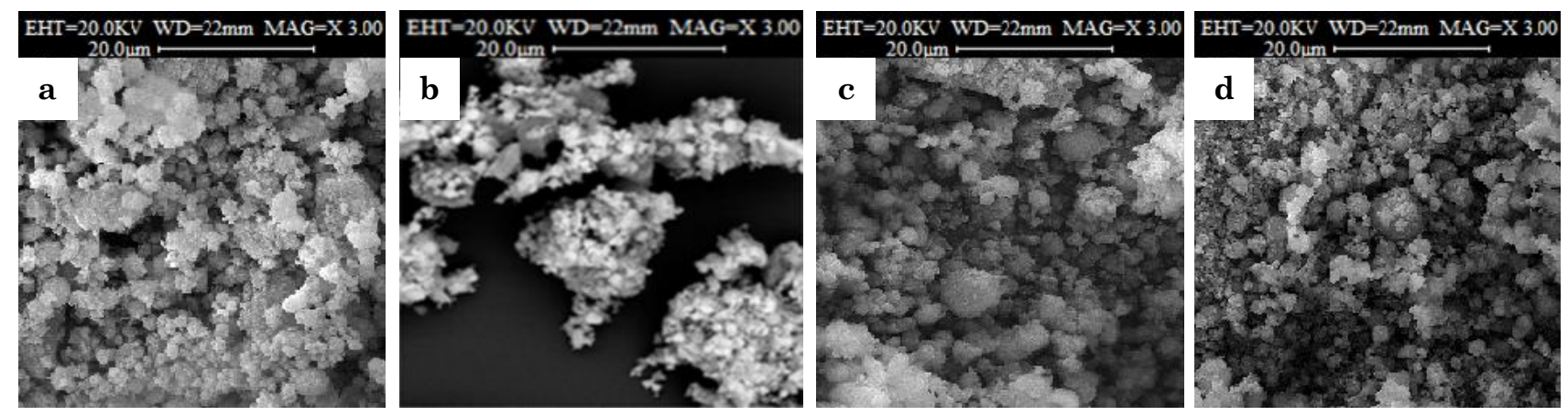

Figure 12. The SEM images of the catalyst precursors dried at (a) $100{ }^{\circ} \mathrm{C}$, (b) $120^{\circ} \mathrm{C}$, (c) $140{ }^{\circ} \mathrm{C}$, and (d) $160{ }^{\circ} \mathrm{C}$ 
to decomposition of hydroxyl or basic nitrate; this weight loss step produces water and nitrogen oxide simultaneously. The third weight loss step is occurred around $380-510{ }^{\circ} \mathrm{C}$ is due to decomposition of hydroxyl or basic carbonates. The weight loss at this step produces water and carbon dioxide concurrently. The DSC curve presented in this figure confirms TGA results and is in agreement with these results. As it can be seen, DSC curve shows three endothermic peaks which first one is observed at lower temperature $\left(190{ }^{\circ} \mathrm{C}\right)$ represents the evaporation of physically adsorbed water. The second endothermic peak at higher temperature (250 $\left.{ }^{\circ} \mathrm{C}\right)$ related to decomposition of the nitrate phases. The third endothermic peak at highest temperature $\left(400{ }^{\circ} \mathrm{C}\right)$ related to the decomposition of the carbonate phases. The thermal analysis (TGA/DSC) results show that after 510 ${ }^{\circ} \mathrm{C}$, the catalyst weight loss is ended and the stable oxidic phases are produced.

The reduction behavior of all of the calcined samples obtained from different precursors was investigated using TPR technique. The obtained TPR profiles are illustrated in Figure 16. As it shown all of the obtained catalysts have shown four distinct reduction peaks. In all of them A and B peaks are attributed to the re- duction of cobalt oxides $\left(\mathrm{Co}_{3} \mathrm{O}_{4} \rightarrow \mathrm{CoO}\right.$ and $\mathrm{CoO}$ $\rightarrow \mathrm{Co}^{\circ}$ ); the $\mathrm{C}$ and $\mathrm{D}$ peaks are related to reduction of iron oxides $\left(\mathrm{Fe}_{2} \mathrm{O}_{3} \rightarrow \mathrm{Fe}_{3} \mathrm{O}_{4}, \mathrm{Fe}_{3} \mathrm{O}_{4}\right.$ $\rightarrow \mathrm{FeO}$ and $\mathrm{FeO} \rightarrow \mathrm{Fe}$ ) and manganese oxides: $\left(\mathrm{Mn}_{2} \mathrm{O}_{3} \rightarrow \mathrm{MnO}\right)$. This figure also shows that the reduction process of the calcined sample obtained from precursor dried at $120^{\circ} \mathrm{C}$ is carried out more easily than the reduction of the

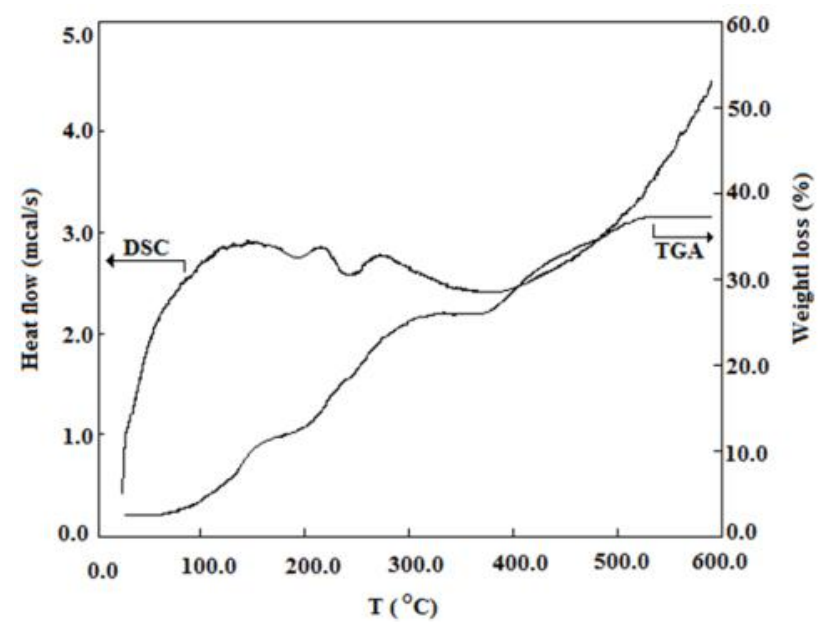

Figure 15. TGA/DSC curves of the Fe-Co$\mathrm{Mn} / \mathrm{MgO}$ catalyst precursor dried at120 ${ }^{\circ} \mathrm{C}$ for $16 \mathrm{~h}$
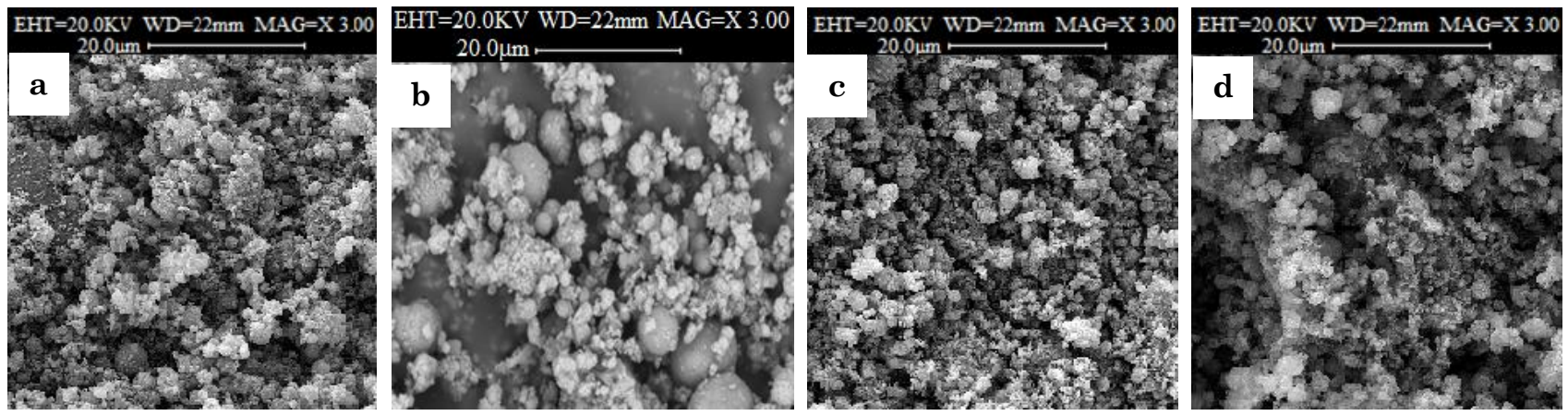

Figure 13. The SEM images of the fresh calcined catalyst obtained from precursors dried at (a) $100{ }^{\circ} \mathrm{C}$, (b) $120^{\circ} \mathrm{C}$, (c) $140{ }^{\circ} \mathrm{C}$, and (d) $160{ }^{\circ} \mathrm{C}$
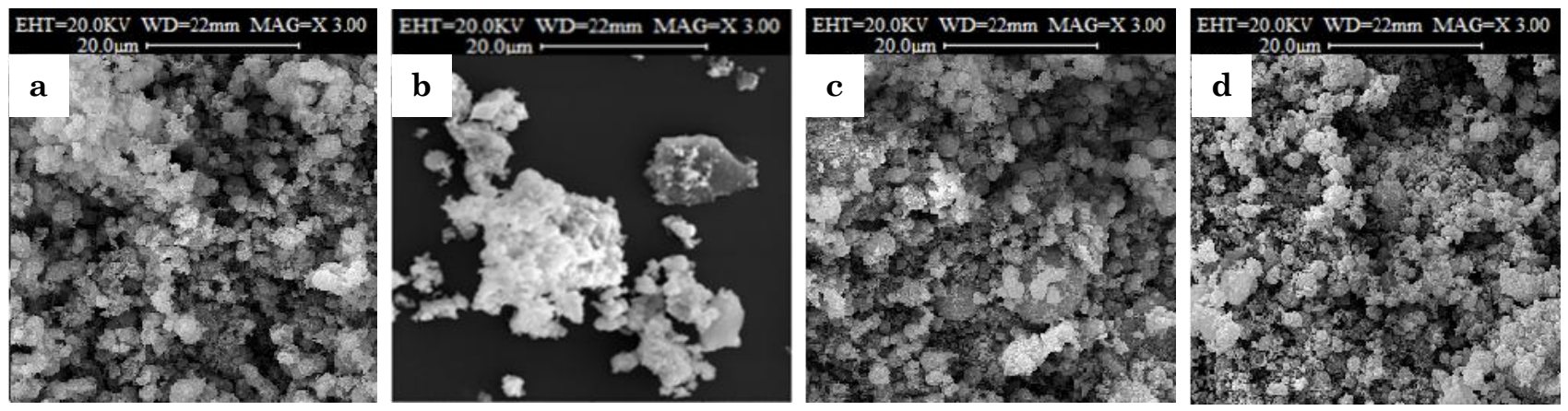

Figure 14. The SEM images of the used calcined catalyst obtained from precursors dried at (a) $100{ }^{\circ} \mathrm{C}$, (b) $120^{\circ} \mathrm{C}$, (c) $140{ }^{\circ} \mathrm{C}$, and (d) $160{ }^{\circ} \mathrm{C}$ 
other samples; this phenomenon supports the better catalytic performance of this sample.

The surface properties of the catalysts were also characterized using BET measurement and the obtained results are presented in Table 3 . According to the obtained results along with increasing the precursor drying temperature the specific area of the catalyst precursors and calcined samples (before and after the test) are increased; these results also showed that the calcined catalyst obtained from the precursor dried at $120{ }^{\circ} \mathrm{C}$ has high specific surface area. The BET results also show that the samples pores size and volume are increased along with precursor drying temperature increasing. In all

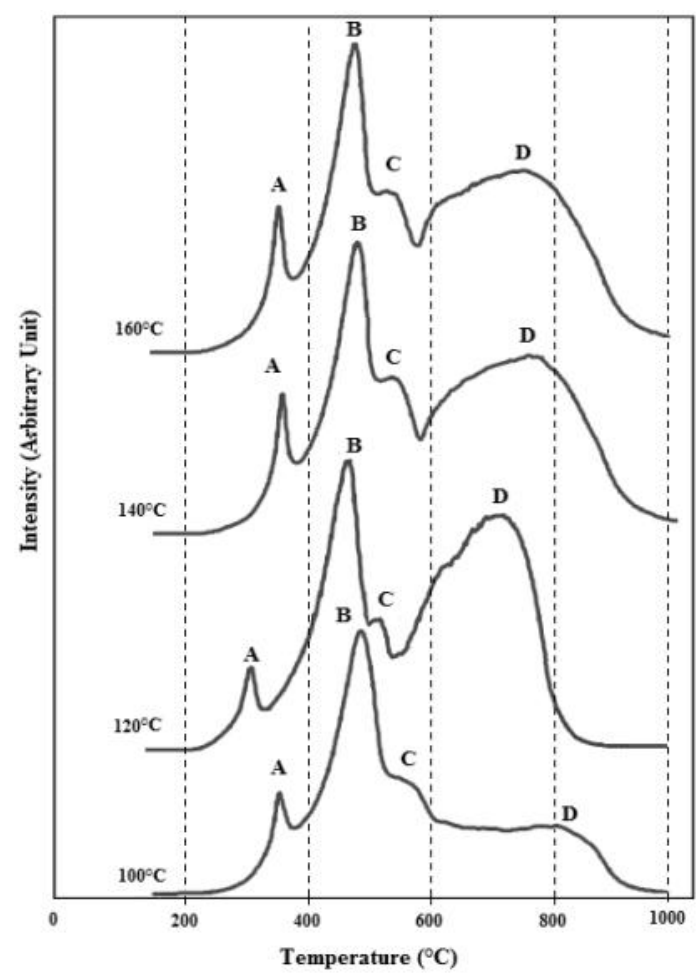

Figure 16. TPR profiles of the Fe-Co- $\mathrm{Mn} / \mathrm{MgO}$ fresh catalysts with different precursor drying temperatures cases the precursors have higher specific surface area than their calcined samples (before and after the test). The BET results show that the precursor drying temperature affect the surface properties and porosity of the precursors and calcined samples.

Since the variation of precursor drying temperature affect the $\mathrm{CO}$ conversion values, this preparation variable affect the $\mathrm{CO}$ consumption and other surface reaction rates (methane production and hydrocarbon formation reactions). The effect of the precursor drying temperature on the various surface reaction rates was investigated and the obtained results are plotted in Figure 17. As it can be observed the catalyst obtained from the precursor which dried at $120{ }^{\circ} \mathrm{C}$ for $16 \mathrm{~h}$ has higher hydrocarbon formation rate and simultaneously has lower methane production rate.

\section{Conclusion}

The supported Fe-Co-Mn catalysts were prepared using co-precipitation method and used for production of $\mathrm{C}_{2}-\mathrm{C}_{4}$ light olefins via

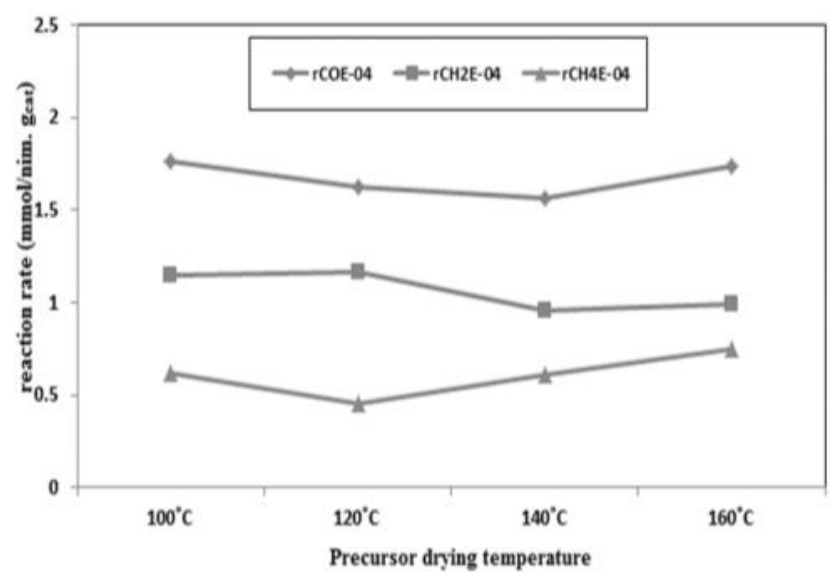

Figure 17. Effect of precursor drying temperature on different surface reactions rates

Table 3. The BET results of the catalysts with different precursor drying temperature in the cases of precursor, fresh and used

\begin{tabular}{|c|c|c|c|c|c|c|c|c|c|}
\hline \multirow{2}{*}{$\begin{array}{l}\text { Catalyst } \\
\text { drying tem- } \\
\text { perature }\end{array}$} & \multicolumn{3}{|c|}{ Precursor } & \multicolumn{3}{|c|}{ Fresh calcined } & \multicolumn{3}{|c|}{ Used calcined } \\
\hline & $\begin{array}{c}\text { SSA } \\
\left(\mathrm{m}^{2} / \mathrm{g}\right)\end{array}$ & $\mathrm{PV}\left(\mathrm{cm}^{3} / \mathrm{g}\right)$ & $\begin{array}{l}\mathrm{PS} \\
\left(\mathrm{A}^{\circ}\right)\end{array}$ & $\begin{array}{c}\text { SSA } \\
\left(\mathrm{m}^{2} / \mathrm{g}\right)\end{array}$ & $\begin{array}{c}\text { PV } \\
\left(\mathrm{cm}^{3 / g}\right)\end{array}$ & $\begin{array}{l}\mathrm{PS} \\
\left(\mathrm{A}^{\circ}\right)\end{array}$ & $\begin{array}{c}\text { SSA } \\
\left(\mathrm{m}^{2} / \mathrm{g}\right)\end{array}$ & $\begin{array}{c}\text { PV } \\
\left(\mathrm{cm}^{3} / \mathrm{g}\right)\end{array}$ & $\begin{array}{l}\text { PS } \\
\left(\mathrm{A}^{\circ}\right)\end{array}$ \\
\hline $100^{\circ} \mathrm{C}$ & 131.23 & $4.15 \times 10^{-2}$ & 21.49 & 90.45 & $2.41 \times 10^{-2}$ & 21.57 & 88.45 & $1.65 \times 10^{-2}$ & 22.43 \\
\hline $120^{\circ} \mathrm{C}$ & 147.00 & $5.75 \times 10^{-2}$ & 22.75 & 99.22 & $1.15 \times 10^{-2}$ & 23.00 & 96.12 & $1.30 \times 10^{-2}$ & 22.96 \\
\hline $140^{\circ} \mathrm{C}$ & 153.23 & $6.14 \times 10^{-2}$ & 24.63 & 103.21 & $3.21 \times 10^{-2}$ & 25.01 & 99.51 & $2.49 \times 10^{-2}$ & 23.61 \\
\hline $160^{\circ} \mathrm{C}$ & 170.05 & $6.79 \times 10^{-2}$ & 23.95 & 109.43 & $3.42 \times 10^{-2}$ & 24.01 & $\begin{array}{c}106.4 \\
1\end{array}$ & $2.67 \times 10^{-2}$ & 25.14 \\
\hline
\end{tabular}

SSA: Specific Surface area; PV: Pore volume; and PS: Pore Size 
CO hydrogenation reaction. The effect of a range of precursor drying conditions (temperature and time) on the catalytic performance and catalyst structure were investigated. It was found that the drying conditions affect the catalytic performance and physicochemical properties of the catalysts. According to the obtained results the best precursor drying conditions were determined as drying time of 16 hours and drying temperature of $120{ }^{\circ} \mathrm{C}$. Characterizations results showed that the drying conditions affect the catalyst reductions behavior, porosity, textural and morphological properties. Since the precursor drying conditions changed the $\mathrm{CO}$ conversion and catalyst activity consequently the surface reactions rate (CO consumption, methane production and hydrocarbon formation reactions) were changed. The catalyst with the best catalytic performance has higher hydrocarbon formation rate and simultaneously has lower methane production rate.

\section{Acknowledgements}

The authors wish to thank Iran National Science Foundation (INSF) of I.R. Iran and Amirkabir University of Technology. This work was supported by Iran National Science Foundation (INSF) of I.R. Iran (grant number: 94027562) and Amirkabir University of Technology.

\section{References}

[1] Shimura, K., Miyazawa, T., Hanaoka, T., Hirata, S. (2015). Fischer-Tropsch Synthesis over Alumina Supported Bimetallic $\mathrm{Co}-\mathrm{Ni}$ Catalyst: Effect of Impregnation Sequence and Solution. J. Mol. Catal. A: Chem., 407: 15-24.

[2] Todica, B., Nowickic, L., Nikacevicb, N., Bukura, D.B. (2016). Fischer-Tropsch Synthesis Product Selectivity over an in Dustrialiron-Based Catalyst: Effect of Process Conditions, Catal. Today, 261: 28-39.

[3] Bhatelia, T., Li, C.E., Sun, Y., Hazewinkel, P., Burke, N., Sage, V. (2014). Chain Length Dependent Olefin Re-Adsorption Model for Fischer-Tropsch Synthesis over $\mathrm{Co}-\mathrm{Al}_{2} \mathrm{O}_{3}$ Catalyst. Fuel Proc. Tech., 125: 277-289.

[4] Zhang, J.P., Sun, Y., Woo, M.W., Zhang, L., $\mathrm{Xu}$, K.Z., (2016). Preparation of Steam Activated Carbon from Black Liquor by Flue Gas Precipitation and Its Performance in Hydrogen Sulfide Removal: Experimental and Simulation Works. J. Taiwan Inst. Chem. E., 59: 395-404.
[5] Gill, S.S., Tsolakis, A., Dearn, K.D., Rodriguez-Fernandez, J. (2011). Combustion Characteristics and Emissions of FischerTropsch Diesel Fuels in IC Engines. Prog. Energ. Combust., 37: 503-523.

[6] Jahangiri, H., Bennett, J., Mahjoubi, P., Wilson, K., Gu, S. (2014). A Review of Advanced Catalyst Development for Fischeretropsch Synthesis of Hydrocarbons from Biomass Derived Syn-gas. Catal. Sci. Tech., 4: 2210-2229.

[7] Sun, Y., Wei, J., Zhang, J.P., Yang, G. (2016). Optimization using Response Surface Methodology and Kinetic Study of FischerTropsch Synthesis using $\mathrm{SiO}_{2}$ Supported Bimetallic Co-Ni Catalyst. J. Nat. Gas Sci. Eng., 28: 173-183.

[8] Zhang, Y., Xiong, H., Liew, K., Li, J., (2005). Effect of Magnesia on Alumina-Supported Cobalt Fischer-Tropsch Synthesis Catalysts. J. Mol. Catal. A: Chem., 237: 172-181.

[9] Luque, R., de la Osa, A.R., Campelo, J.M., Romero, A.A., Valverde, J.L, Sanchez, P. (2012). Design and Development of Catalysts for Biomass-To-Liquid-Fischer-Tropsch (BTLFT) Processes for Biofuels Production. Energ. Environ. Sci., 5: 5186-5202.

[10] de Beer, M., Kunene, A., Nabahot, D., Claeys, M., Steen, E.van. (2014). Technical and Economic Aspects of Promotion of CobaltBased Fischer-Tropsch Catalysts by Noble Metals-A Review. J. S. Afr. I Min. Metall., 114: 157-165.

[11] Zhao, Y-H., Song, Y-H., Hao, Q-Q., Wang, YJ., Wang, W., Liu, Z-T., Zhang, D., Liu, Z-W., Zhang, Q-J., Lu, J., (2015). Cobalt-Supported Carbon and Alumina Co-Pillared Montmorillonite for Fischer-Tropsch Synthesis. Fuel. Proc. Tech., 138: 116-124.

[12] Yang, J., Ma, W.P., Chen, D., Holmen, A., Davis, B.H. (2014). Fischer-Tropsch Synthesis: A Review of the Effect of CO Conversion on Methane Selectivity. Appl. Catal. A Gen., 470: 250-260.

[13] Khodakov, A.Y., Chu, W., Fongarland, P. (2007). Advances in the Development of Novel Cobalt Fischer-Tropsch Catalysts for Synthesis of Long-Chain Hydrocarbons and Clean Fuels. Chem. Rev., 107(5): 1692-1744.

[14] Trépanier, M., Tavasoli, A., Dalai, A.K., Abatzoglou, N. (2009). Co, Ru and K Loadings Effects on the Activity and Selectivity of Carbon Nanotubes Supported Cobalt Catalyst in Fischer Tropsch Synthesis. Appl. Catal. A: Gen., 353(2): 193-202.

[15] Jothimurugesan, K., Gangwal, S.K. (1998). Regeneration of Zinc Titanate $\mathrm{H}_{2} \mathrm{~S}$ Sorbents, Ind. Eng. Chem. Res., 37: 1929-1933. 
[16] Van der Laan, G.P., Beenackers, A.A.C.M. (1999). Kinetics and Selectivity of the FischerTropsch Synthesis: A Literature Review. Catal. Rev. Sci. Eng., 41: 255-318.

[17] González-Cortés, S.L., Rodulfo-Baechler, S.M.A., Oliveros, A., Orozco, J., Fontal, B., Mora, A.J., Delgado, G. (2002). Synthesis of Light Alkenes on Manganese Promoted Iron and Iron-Cobalt Fischer-Tropsch Catalysts. React. Kinet. Catal. Lett., 75: 3-12.

[18] Keyser, M.J., Everson, R.C., Espinoza, R.L. (1998). Fischer-Tropsch Studies with CobaltManganese Oxide Catalysts: Synthesis Performance in a Fixed Bed Reactor. Appl. Catal. A: Gen., 171: 99-107.

[19] Cabet, C., Roger, A.C., Kiennemann, A., Lakamp, S., Pourroy, G. (1998). Synthesis of New Fe-Co Based Metal/Oxide Composite Materials: Application to the Fischer-Tropsch Synthesis. J. Catal., 173: 64-73.

[20] Tihay F, Roger A. C, Kiennemann A, Pourroy, G, (2000) Fe-Co based metal/spinel to produce light olefins from syngas, Catal. Today 58: 263-269.

[21] Barrault, J. (1982). Selective Hydrogenation of Carbon Monoxide on Supported Iron or Cobalt Catalysts. Effects of Manganese Oxide and (Or) Chlorine. Stud. Surf. Sci. Catal., 11: 225-231.

[22] Barrault, J., Forquy, C., Menezo, J., Maurel, R. (1980). Selective of CO to Light Olefins with Alumina-Supported Iron Catalysts. React. Kinet. Catal. Lett., 15: 153-158.

[23] Barrault, J., Forquy, C., Perrichon, V. (1983). Effects of Manganese Oxide and Sulphate on Olefin Selectivity of Iron Supported Catalysts in The Fischer-Tropsch Reaction. Appl. Catal. A: Gen., 5: 119-125.

[24] Arsalanfar, M., Mirzaei, A.A., Bozorgzadeh, H.R. (2012). Effect of Calcination Conditions on the Structure and Catalytic Performance of $\mathrm{MgO}$ Supported Fe-Co-Mn Catalyst for CO Hydrogenation. J. Nat. Gas. Sci. Eng., 6: 1-13.

[25] Arsalanfar, M., Mirzaei, A.A., Bozorgzadeh, H.R. (2013). Effect of Preparation Method on Catalytic Performance, Structure and Surface Reaction Rates of MgO Supported Fe-Co-Mn Catalyst for CO Hydrogenation. J. Ind. Eng. Chem., 19: 478-487.

[26] Arsalanfar, M., Mirzaei, A.A., Bozorgzadeh, H.R., Atashi, H. (2012). Effect of Process Conditions on the Surface Reaction Rates and Catalytic Performance of MgO Supported FeCo-Mn Catalyst for CO Hydrogenation. J. Ind. Eng. Chem., 18: 2092-2102

[27] Arsalanfar, M., Mirzaei, A.A., Bozorgzadeh, H.R., Samimi, A., Ghobadi, R. (2014). Effect of Support and Promoter on the Catalytic
Performance and Structural Properties of the Fe-Co-Mn Catalysts for Fischer-Tropsch Synthesis. J. Ind. Eng. Chem., 20: 1313-1323.

[28] An, X., Wu, B., Hou, W., Wan, H., Tao, Z., Li, T., Zhang, Z., Xiang, H., Li, Y., Xu, B., Yi, F. (2007). The Negative Effect of Residual Sodium on Iron-Based Catalyst for FischerTropsch Synthesis. J. Mol. Catal. A: Chem., 263: 266-272.

[29] Zennaro, R., Tagliabue, M., Bartholomew, C.H. (2000). Kinetics of Fischer-Tropsch Synthesis on Titania-Supported Cobalt. Catalysis Today, 58: 309-319.

[30] Levenspiel, O. (1999). Chemical Reaction Engineering, 3th ed., Wiley, New York, Chapter 24,

[31] Xue, L., Zhang, C.B., He, H., Teraoka, Y. (2007). Catalytic Decomposition of $\mathrm{N}_{2} \mathrm{O}$ over $\mathrm{CeO}_{2}$ Promoted $\mathrm{Co}_{3} \mathrm{O}_{4}$ Spinel Catalyst. Appl. Catal. B: Environmental, 75: 167-174.

[32] Lin, H.Y., Chen, Y.W. (2004). The Mechanism of Reduction of Cobalt by Hydrogen. Mater. Chem. Phys., 85: 171-175.

[33] Jozwiak, W.K., Kaczmarek, E., Maniecki, T.P., Ignaczak, W., Maniukiewicz, W. (2007). Reduction Behavior of Iron Oxides in Hydrogen and Carbon Monoxide Atmospheres. Appl. Catal. A: Gen., 326: 1727.

[34] Lögdberg, S., Tristantini, D., Borg, Ø., Ilver, L., Gevert, B., Järås, S., Blekkan, E.A., Holmen, A. (2009). Hydrocarbon Production via Fischer-Tropsch Synthesis from $\mathrm{H}_{2}$-poor Syngas over Different $\mathrm{Fe}-\mathrm{Co} / \mathrm{Y}^{-} \mathrm{Al}_{2} \mathrm{O}_{3}$ Bimetallic Catalysts. Appl. Catal. B: Env, 89: 167-182.

[35] Li, T., Yang, Y., Tao, Z., Zhang, C., Xiang, H., Li, Y. (2009). Study on an Iron-Manganese Fischer-Tropsch Synthesis Catalyst Prepared from Ferrous Sulfate. Fuel. Proc. Tech., 90: 1247-1251.

[36] Li, T., Yang, Y., Zhang, C., Tao, Z., Wan, H., An, X., Xiang, H., Li, Y. (2007). Effect of Manganese Incorporation Manner on an IronBased Catalyst for Fischer-Tropsch Synthesis. J. Nat. Gas Chem, 16: 244-251.

[37] Zhang, C-H., Yang, Y., Teng, B-T., Li, T-Z., Zheng, H-Y., Xiang, H-W., Li, Y-W. (2006). Study of an Iron-Manganese Fischer-Tropsch Synthesis Catalyst Promoted with Copper. J. Catal, 237: 405-415

[38] Li, T., Yang, Y., Zhang, C., An, X., Wan, H., Tao, Z., Xiang, H., Li, Y., Yi, F., Xu, B. (2007). Effect of Manganese on an Iron-Based Fischer-Tropsch Synthesis Catalyst Prepared from Ferrous Sulfate. Fuel, 86: 921-928 